This may readily be effected from three to six months after the injections. It is claimed that after three injections with toxin-antitoxin 70 to 90 per cent. of those treated are found to be immune after eight weeks.

Interesting figures have been published showing that in America of 90,000 Schick-tested, immunized, and treated school children, 14 got diphtheria, while of a similar number not tested or treated 56 acquired the disease. An extensive campaign has recently been started in New York to popularize antidiphtheria immunization. It would seem advisable to apply the system whenever a careful study of the epidemiological situation convinces us that it may be resorted to with advantage.

Another application of the Schick test is in the clinical diagnosis of diphtheria. A true case of faucial diphtheria will give a positive Schick reaction, but a carrier of virulent diphtheria bacilli will give a negative reaction. One observer recently noted twelve cases of diphtheria in children with a negative Schick reaction, but in the majority of the patients the disease proved to be nasal diphtheria. The test is of the greatest value in school epidemics. Children can be tested, and within twenty-four hours may be divided into two groups-the immune and the susceptible.

One of the chief difficulties in the use of the Schick test is the pseudo-reaction, which is due to the presence in the toxic filtrates of some substance which is more stable than the specific one, and which causes rise of temperature and other reactions. It is important that the toxin-antitoxin mixture should not be used after exposure to a temperature below $0^{\circ} \mathrm{C}$.

The most favourable age for the administration of diphtheria prophylactic is from 1 to 5 years.

I am much indebted to Dr. F. Douglas Turner, medical superintendent of the Royal Eastern Counties Institution, Colchester, for allowing me to publish this article and for his valuable advice regarding the work. My thanks are due also to Dr. R. A. O'Brien, director of the Wellcome Research Laboratories, for giving me suggestions in the necessary technique.

\section{THE MORTALITY OF ACUTE APPENDICITIS.}

JOHN B. HUNTER, M.CH., F.R.C.S.,

SURGEON, ROYAL NORTHERN HOSPITAL; LATE SURGICAL REGISTRAR, UNIVERSTTY COLLEGE HOSPITAL.

I pUbLIsH the following figures in the belief that they indicate that the safest plan to adopt in treating acute appendicitis is to operate at once irrespective of the duration of the disease and of the local conditions obtaining.

All authorities are agreed that there is a steady increase in the incidence of appendicitis.

\begin{tabular}{|c|c|c|c|c|c|c|c|c|}
\hline \multicolumn{9}{|c|}{ Deaths from Appcndicitis in England and Wales } \\
\hline 1915 & $\cdots$ & $\cdots$ & $\cdots$ & $\begin{array}{l}\text { Male. } \\
1441\end{array}$ & & $\begin{array}{c}\text { Female. } \\
1062\end{array}$ & & $\begin{array}{l}\text { Total. } \\
2503\end{array}$ \\
\hline 1916 & $\cdots$ & ... & $\ldots$ & 1474 & & 1129 & & 2603 \\
\hline 1917 & $\ldots$ & . & $\ldots$ & 1390 & ...... & 1053 & & 2443 \\
\hline 1918 & ... & $\cdots$ & $\ldots$ & 1298 & ...... & 1118 & $\cdot$ & 2316 \\
\hline 1919 & ... & $\cdots$ & $\ldots$ & 1278 & ....... & 1151 & & 2429 \\
\hline 1920 & ... & & $\ldots$ & 1389 & . & 1142 & & 2531 \\
\hline 1321 & $\cdots$ & & $\cdots$ & 1474 & $\cdots$ & 1237 & & 2711 \\
\hline 1922 & ... & $\ldots$ & $\ldots$ & 1524 & ....... & 1211 & ....... & 2735 \\
\hline 192 & .. & ... & $\ldots$ & 1608 & $\ldots \ldots$ & 1218 & $\ldots$. & 2826 \\
\hline 192 & ... & $\ddot{*}$ & $\cdots$ & 1545 & . & 1211 & & 2756 \\
\hline 1925 & & 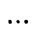 & $\ldots$ & 1624 & & 1238 & & 2862 \\
\hline
\end{tabular}

These figures show an increase in mortality, but do not indicate the percentage mortality of the disease.

Adams ${ }^{2}$ recently brought forward figures that had been collected from St. Thomas's Hospital, together with others already published by Love ${ }^{2}$ from the London Hospital. They showed that the percentage rate of mortality in appendicitis is by no means as low as the general impression would indicate. In . both these hospitals two methods are adopted in the treatment of the disease-one in which immediate operation is undertaken, and the other where delay is advocated if the patient is in the.third to sixth day of the disease. The patient is watched, and if the condition is progressive, operation is undertaken.

The percentage case mortality is weighted by the cases of general peritonitis; Adams remarks that, if we omit these cases, " the St. Thomas's mortality comes down to 2.7 per cent. and that of the London to 3.5. These are very respectable figures, and seem to me to justify the gospel of immediate surgical treatment."

Further improvement in these figures can only be obtained by the early recognition of the disease, and especially is this the case in children, in whom the interval between the disease, being limited to the appendix region and general peritonitis is frequently short. The advantage of delay in operation seems very doubtful; all its advocates appear to be agreed that it can only be followed under hospital conditions. This teaching must have its repercussion first on the general practitioner and later on the general public, and does not appear to me to be safe.

When an analysis of the cases treated on delayed lines is made it appears that at the London Hospital 109 cases out of a total of 341 were " unsuccessfully delayed," and at St. Thomas's Hospital 71 out of 214 in each case approximately one in three. It seems probable that the cases " unsuccessfully delayed" must be in a worse condition to withstand operativo intervention than if they had been operated on when first diagnosed; the mortality in these cases is in fact higher than that of cases of local abscess which underwent immediate operation-at the London Hospital 6.4 per cent. compared with 4.6 per cent., and at St. Thomas's Hospital 14 per cent. compared with 4.2 per cent.

The figures at University College Hospital are taken for five years-from 1921 to 1925 . The practice at this hospital has been to treat all cases diagnosed appendicitis by an emergency operation, irrespective of the day of the disease or the presence or absence of an abscess. Further, all cases diagnosed appendicitis are admitted to the surgical side, and are therefore under " one man control "-a point of considerable importance, as Adams has pointed out.

We therefore get in these figures the result on the case mortality of one quite definite line of treatment-namely, immediate operation. The cases have been divided into those that were drained and those cases in which the abdominal wall was sutured and no drainage employed. This gives a rough idea of the character of the disease, allowing for slight variations in the treatment of different operators; those cases that were drained either had general peritonitis or considerable collections of localized pus. The total number of cases was 602 ; of these, 274 were closed and 328 drained; 21 died ( 3.5 per cent.).

The number of cases of general peritonitis amongst these was 62 , or about one-tenth, and the case mortality was 11 -a percentage of 17.7. The mortality in the remaining 540 cases was 10 (1.8 per cent.). Two died of obstruction other than paralytic ilcus, five with localized abscess, one of abscess of the lung, one from pneumonia, and one from spreading cellulitis of the abdominal wall. Among the cases dealt with, 95 were children under the age of 14 ; the mortality in these cases was 6-a percentare of 6.3 as compared with the above average of 3.5 ; of these 6 cases 5 died of general peritonitis. These figures bear out the seriousness of the disease in children, and the necessity of early diagnosis and immediate operation.

This fact is further brought out in the RegistrarGeneral's figures for appendicitis and typhlitis for 1925, in which the deaths are arranged according to ages.

\begin{tabular}{cccccrcrrr} 
Years. & & & & \multicolumn{4}{c}{ Males. } & \multicolumn{3}{c}{ Females. } & Total. \\
$0-15$ & $\ldots$ & $\ldots$ & $\ldots$ & $\ldots$ & 415 & $\ldots \ldots$ & 341 & $\ldots \ldots$ & 756 \\
$15-25$ & $\ldots$ & $\ldots$ & $\ldots$ & $\ldots$ & 307 & $\ldots \ldots$ & 180 & $\ldots \ldots$ & 487 \\
$25-45$ & $\ldots$ & $\ldots$ & $\ldots$ & $\ldots$ & 351 & $\ldots \ldots$ & 263 & $\ldots \ldots$ & 614 \\
$45-65$ & $\ldots$ & $\ldots$ & $\ldots$ & $\ldots$ & 383 & $\ldots \ldots$ & 323 & $\ldots \ldots$ & 706 \\
$65-75$ & $\ldots$ & $\ldots$ & $\ldots$ & $\ldots$ & 126 & $\ldots \ldots$ & 96 & $\ldots \ldots$ & 222 \\
75 and & over & $\ldots$ & $\ldots$ & $\ldots$ & 42 & $\ldots \ldots$ & 35 & $\ldots \ldots$ & 77
\end{tabular}

It is stated by most authorities that the third to the sixth day is the dangerous stage at which to operate. It would appear probable that this statement rests on false premisses. Where immediato operation has not been advocated the cases are treated medically, and a number of 
these successfully respond to this treatment. But the others, owing to extension of the disease, require surgical intervention, as is shown above, in approximately one in three of this type of case; and these being the worst cases, the mortality is higher, and gives the impression that this period is a peculiarly dangerous one. It does not appear to be so if immediate operation is undertaken.

Although it is a little difficult accurately to determine the day of the disease, I have done so as far as possible with these 21 fatal cases, and give for comparison the figures for all cases. The duration of the disease at the time of operation is shown in the following table.

\begin{tabular}{cccccccccr} 
Duration of Disease. & \multicolumn{4}{c}{} & \multicolumn{4}{c}{ Deaths. } & \multicolumn{3}{c}{ All Cases. } \\
24 hours & $\ldots$ & $\ldots$ & $\ldots$ & $\ldots$ & $\ldots$ & 2 & $\ldots \ldots$ & 173 \\
$48 \quad$, & $\ldots$ & $\ldots$ & $\ldots$ & $\ldots$ & $\ldots$ & 7 & $\ldots \ldots$ & 142 \\
3 days & $\ldots$ & $\ldots$ & $\ldots$ & $\ldots$ & $\ldots$ & 1 & $\ldots \ldots$ & 91 \\
4 y, & $\ldots$ & $\ldots$ & $\ldots$ & $\ldots$ & $\ldots$ & 2 & $\ldots \ldots$ & 57 \\
5 days and over & $\ldots$ & $\ldots$ & $\ldots$ & $\ldots$ & 6 & $\ldots \ldots$ & 137 \\
Unknown & $\ldots$ & $\ldots$ & $\ldots$ & $\ldots$ & $\ldots$ & 3 & $\ldots \ldots$ & 3
\end{tabular}

Of the six fatal cases shown of five days and over, one was wrongly diagnosed salpingitis and operation was delayed, and one was admitted and treated medically for ten days.

If we take the case mortality up to three days, we see that it is 9 in 315, and from three days up to five days and over it is 9 in 285; further, four of these deaths occurred in patients over the seventh day of the disease. This does not appear to be an undue preponderance in the case fatality between the third and sixth day.

If the relative figures of cases drained or sutured are taken as an index, the severity of the disease certainly appears to increaso with the duration.

Table showing that the Number of Cascs drained increases with the duration of the Discase.

Duration of Disease.

Closed. Drained

$\begin{array}{lcccccrcr}24 \text { hours } & \ldots & \ldots & \ldots & \ldots & \ldots & 125 & \ldots \ldots & 48 \\ 48 \text {, } & \ldots & \ldots & \ldots & \ldots & \ldots & 60 & \ldots \ldots & 82 \\ 3 \text { days } & \ldots & \ldots & \ldots & \ldots & \ldots & 33 & \ldots \ldots & 58 \\ 4 \text {, } & \ldots & \ldots & \ldots & \ldots & \ldots & 20 & \ldots \ldots & 36 \\ 5 \text { days and over } & \ldots & \ldots & \ldots & \ldots & 36 & \ldots \ldots & 101 \\ \text { Unknown } & \ldots & \ldots & \ldots & \ldots & \ldots & - & \ldots \ldots & 3\end{array}$

The presence of pus, however, is the indication for drainage, and we should expect to find it on the third day and over rather than in the earlier period. These figures, then, represent a pathological process rather than the severity of the disease, as it is well known that numbers of cases with abscess formation recover without surgical intervention.

In discussing the influence of immediate operative treatment on the mortality of appendicitis any other factor that is likely to influence that mortality should be taken into account, and in my opinion the method of approach is of considerable importance.

In the greater number of the cases quoted above the muscle-splitting incision was employed. The advantage of this appears to be that the diseased area is directly exposed, frequently the whole operation is conducted in a small compartment completely shut off from the general peritoneal cavity, and the natural extension of the disease, if pus be present, can be followed into the pelvis, very often without grossly soiling the rest of the peritoneum. Naturally this point is not of great importance if general peritonitis is already present, but in a number of cases this fact cannot be accurately determined before the abdomen is opened. I therefore think that McBurney's incision plays an important part in the successful treatment of acute appendicitis.

The figures I have given,- showing 1.8 per cent. case mortality, excluding the general peritonitis cases, and 3.5 per cent. for all cases, appear to me to be further evidence in favour of immediate operation in acute appendicitis.

I am indebted to the surgeons at University College Hospital for permission to use these statistics.

\section{REFERFACES}

1 British Medical Joumal, April 18th, 1925. 2 Brit. Journ. Surg.,

\section{ANAPHYLAXIS AND ULTRA-VIOLET LIGHT TREATMEN'T.}

\section{ALEXANDER BRYCE, M.D., C.M.Glasg.;} BIRMINGHAM.

Ax.pryylaxis has been defined as hypersensitiveness to foreign proteins-either direct protein extracts or the products of various micro-organisms not necessarily pathogenic, and not in themselves toxic. The alarming symptoms and depression are said to be explained by the formation of an antibody, probably a very insoluble precipitate in the blood serum of the patient, profoundly interfering, like histamine, with the capillary circulation and producing an asphyxia in the tissues themselves.

The following diseases have been attributed to its operation: asthma, bronchitis, hay fever, certain skin affections, angioneurotic oedema, cyclic vomiting, periodic diarrhoea, and the migraine-epilepsy syndrome.

Many specific methods have been used in the treatment of these disorders, but the only one common to the whole group is the use of peptone in small gradually increasing doses, never large enough to produce any pronounced reaction. The resultant immunizing action is said to be due to the detachment from the cells of antibodies which destroy the antigen in the blood. Auld, on the other hand, regards the antigen-antibody product as the cause of the anaphylactic shock. What is perhaps of more significance than either suggestion is the fact that leucocytosis is certainly produced by the reaction to peptone and other definite chemical substances, the bone marrow being stimulated to produce with great rapiditit at least a double quantity of leucocytes. Though we have no very clear picture of the way in which the curative results are brought about, yet as similar results accrue from the use of ultra-violet rays in many of the maladies mentioned, and as we have some knowledge of the method whereby they do their work, it occurred to me that consideration of the facts might in some degree illumine the subject. It must be premised that by no means all cases of asthma or allied maladies are due to protein sensitization. Some may be due to nervous reflexes, some to hereditary diathesis, whilst others may require the combination of all three factors. I propose, therefore, to give the results of ultraviolet therapy in a typical case of spasmodic asthma and bronchitis of the most severe character, in a typical case of protein sensitization, and in a typical case of asthma alternating with eczema.

Miss B., aged 45, had been subject to the most violent attacks of asthma for over twenty years, each attack confining her to bed for many days and sometimes weeks, where she would lie with cyanosed countenance, struggling for breath, wheezing râles with slight expectoration being heard two or three rooms away Sometimes slight relief was obtained by pitrenalin, sometimes by adrenaline, and sometimes by morphine, but her life was a burden and the last few attacks looked as if they might be fatal. Early in $1924 \mathrm{I}$ commenced irradiation of the back and chest with the in 1924 I commenced irradiation of the back and chest with the quartz mercury vapour lamp on the one and the carbon arc lamp on the other, alternating after a few minutes. From the first months ere the wheezing quite disappeared. For the succeeding year a weekly treatment has enabled her to live without any discomfort or even suggestion of asthma and bronchitis.

Miss E. S. for many years had sudden violent attacks of suffocative feeling in the throat, with a sensation as if pepper had been sprinkled over it, followed by intense wheezing inspiratory and expiratory efforts, mucous râles, and a sense of impending tory and expiratory efforts, mucous râles, and a sense of impending
death. Many kinds of treatment were tried by laryngologists and death. Many kinds of treatment were tried by laryngologists and physicians, including pollantine and peptone; finally adrenaline or less, although it left the patient in a most exhausted condition. Skin testing elicited the fact that acid fruits, and especially raw apples, appeared to engender these attacks, and care in dieting reduced the attacks considerably but not completely. For close upon twenty months this patient has been acting as my close upon in the assistant in the treatment of cases by ultra-violet light rays, besides which she has had many direct irradiations over the chest and back. For over a year she has

Miss N. L., aged 28, has been an asthmatic from birth: The
Mite occasional dietetic trespass. asthmatic attacks were suddenly replaced by universalized eczemà for which many kinds of treatment, both external and internal, were tried for a year without success. She then consented to try ultra-violet light, with the result that six treatments in three weeks completely cured the eczema, and she is persevering with the irradiations in the hope of completely eradicating the asthma. 